\title{
PEMBERIAN SUPLEMEN KOLAGEN TERHADAP KADAR GULA DARAH PADA WANITA MENOPAUSE
}

\author{
Dewi Rosalina', Sri Dinengsih², Risza Choirunissa \\ 1,2,3 Kebidanan, Universitas Nasional Jln RM Harsono no 1 Jakarta Selatan \\ 1 email : dewirosalina94@gmail.com, \\ ${ }^{2}$ email : sridinengsih@civitas.unas.ac.id \\ ${ }^{3}$ email : risza.choirunissa@gmail.com
}

\section{ABSTRACT GIVING COLLAGENT SUPPLEMENTS ON BLOOD SUGAR LEVELS IN MENOPAUSE WOMEN}

Background: Menopause is a natural process experienced by every woman aged around 48-54 years. The factors that affect menopause at the beginning are usually due to indiscriminate food consumption so that menopausal women experience diabetes mellitus which is increasing where it is known that blood sugar levels can increase.

Purpose: This study was to determine the effect of collagen supplementation on blood sugar levels in menopausal women suffering from Diabetes Mellitus in the Work Area of the Curug Public Health Center, Tangerang Regency, 2020.

Method: This study was a quasi-experimental study with a One Group Pretest-Postest Design without a control group. The sampling technique used was total sampling. The sample in this study consisted of 20 menopausal women who suffered from diabetes mellitus in June-July 2020.

Results: the results of this study indicated that blood sugar levels in menopausal women before being given collagen supplements were 277.15 and after being given collagen supplements 260.30. The results of the Paired $t$-test analysis showed that there was no effect of blood sugar levels in menopausal women suffering from diabetes mellitus, before and after giving collagen supplements with a value of Pvalue $=0.471$.

Conclusion : the conclusion is that there is no effect of blood sugar levels before and after giving collagen supplements to menopausal women suffering from diabetes mellitus in the Work Area of the Curug Public Health Center, Tangerang Regency, 2020

Suggestion: It is hoped that further research can carry out further research on collagen supplementation in menopausal women on blood sugar levels with a longer / longer study time and add other variables that have not been studied.

Keywords: Menopause, Blood Sugar, Collagen.

\section{ABSTRAK}

Latar Belakang: Menopause merupakan proses alamiah yang dialami setiap wanita yang berusia sekitar 48-54 tahun, faktor yang mempengaruhi menopause pada awal biasanya dikarenakan konsumsi makanan yang sembarangan sehingga wanita menopause mengalami diabetes mellitus semakin meningkat dimana telah ketahui kadar gula darah dapat meningkat.

Tujuan : Penelitian ini untuk mengetahui pengaruh pemberian suplemen kolagen terhadap kadar gula darah pada wanita menopause yang menderita Diabetes Mellitus di Wilayah Kerja Puskesmas Curug Kabupaten Tangerang Tahun 2020.

Metode : Penelitian ini quasi-experiment dengan rancangan One Group Pretest-Postest Design tanpa adanya kelompok kontrol.Teknik pengambilan sampel yang digunakan adalah total sampling. Sampel dalam penelitian ini berjumlah 20 wanita menopause yang menderita diabetes mellitus pada bulan juni-juli tahun 2020

Hasil penelitian ini menunjukkan bahwa kadar gula darah pada wanita menopause sebelum diberikan suplemen kolagen 277,15 dan sesudah diberikan suplemen kolagen 260,30. Hasil analisis Uji Paired t-test menunjukan bahwa tidak ada pengaruh kadar gula darah pada wanita menopause yang menderita diabetes mellitus, sebelum dan sesudah pemberian suplemen kolagen dengan nilai Pvalue =0,471.

Kesimpulan tidak ada pengaruhkadar gula darah sebelum dan setelah pemberian suplemen kolagen pada wanita menopause yang menderita diabetes mellitus di Wilayah Kerja Puskesmas Curug Kabupaten Tangerang Tahun 2020 
Saran : diharapkan untuk penelitian selanjutnya dapat melakukan penelitian lebih lanjut mengenai suplemen kolagen pada wanita menopause terhadap kadar gula darah dengan waktu penelitian yang lebih panjang/lamadan menambahkan variable-variabel lain yang belum di teliti.

Kata Kunci :Menopause, Kadar Gula Darah ,Suplemen Kolagen,

\section{PENDAHULUAN}

Menopause merupakan istilah kedokteran yang menyatakan saat dimana seorang wanita mengalami berhenti haid yaitu tidak mendapat haid lagi dalam 12 bulan berturut-turut. Menopause adalah proses alamiah yang dialami setiap wanita yang berusia sekitar 48-54 tahun. Gangguan haid ini merupakan akibat dari menurunnya kadar hormone estrogen (Santoso \& Ismail, 2009).

Tidak diproduksinya lagi hormon estrogen akan menyebabkan banyak kerentanan kesehatan. Hilangnya hormon-hormon perempuan juga mengakibatkan mudahnya timbul penyakitpenyakit degeneratif, seperti jantung, hipertensi, diabetes, kanker, stroke, osteoporosis (Waluyo \& Putra, 2010).

Penyakit autoimun seperti Diabetes Melitus menyebabkan terjadinya menopause dini. Pada wanita perokok juga terjadi usia menopause lebih awal, faktor yang juga mempengaruhi menopause lebih awal biasanya dikarenakan konsumsi makanan yang sembarangan (Sari, Indarwati, 2012).

Kolagen terlibat dalam pembentukan jaringan fibrillar dan microfibrillar dari matriks ekstraseluler dan membran basement. Protein fibrilar menyusun protein utama komponen tulang, tulang rawan, tendon, kulit dan lainnya bentuk jaringan ikat. Saat ini, kolagen telah menjadi permintaan bahan menuju pengembangan makanan sehat. Produksi kolagen dalam tubuh berkurang seiring bertambahnya usia dan pola makan yang tidak baik. Saat ini banyak Kolagen yang telah dicampur bersama dalam berbagai makanan dan produk minuman. Saat ini, ada banyak produk kolagen komersial yang tersedia dari berbagai sumber yang dipasarkan secara lokal(Beloaufa,2018)

Manfaat kolagen terhadap kesehatan yang telah menyebabkan pembentukan industri suplemen kolagen. Karena fitur penyerapan kelembaban, kolagen dan fraksinya telah menunjukkan fungsi utama sebagai serat dan sumber protein pada tubuh manusia. Saat ini, minuman kolagen adalah minuman lain yang menjadi tren di pasar global. Ada banyak produk dirilis oleh produsen seperti kolagen kedelai, cocoa collagen, cappuccino collagen, coffee collagen, jus dengan kolagen dan minuman sarang burung dengan kolagen. Pemberian minuman dengan kolagen dapat membantu meningkatkan kapasitas alami tubuh untuk menghasilkan jaringan lemak. Umumnya, minuman kolagen mengklaim untuk merangsang mekanisme pembuatan kolagen di tubuh, yang pada gilirannya akan mempromosikan jaringan dan tubuh mengurangi keriput dan kendur kulit. (Alves 2017)

Hormon estrogen dan progesteron ikut mempengaruhi respon sel-sel tubuh terhadap insulin. Setelah menopause, perubahan tingkat hormon tubuh dapat memicu fluktuasi kadar gula darah. Hal ini menyebabkan kadar gula darah lebih sulit diprediksi dibandingkan pada masa sebelum menopause. Jika kadar gula darah tidak terkontrol, maka akan memiliki risiko komplikasi diabetes yang lebih tinggi (Karyati,2016, Hasyim,2015,Bilek 2015,)

Sejak saat publikasi studi Women's Health Initiative (WHI), manajemen gejala menopause menjadi lebih kompleks karena meningkatnya kesadaran akan risiko yang terkait dengan terapi penggantian hormon (HRT). Saat ini, berbagai pilihan manajemen tersedia. Beberapa wanita menggunakan obat resep, dan yang lain menggunakan strategi perawatan diri, termasuk modifikasi gaya hidup, persiapan tanpa resep dan terapi komplementer dan alternatif, seperti persiapan herbal, program latihan dan teknik relaksasi. Teknik relaksasi terdiri dari sekelompok intervensi perilaku. Mereka menganggap relatif tidak berbahaya, tetapi efektivitasnya dalam mengobati gejala. Menurut data WHO, secara global prevalensi diabetes mellitus akan meningkat dari 171 juta orang pada tahun 2000 menjadi 366 juta pada tahun 2030.

Menurut data Dinas Kesehatan Kabupaten Jepara, jumlah kasus DM yang diperoleh dari laporan seluruh Puskesmas di wilayah Kabupaten Jepara pada tahun 2011 adalah sebanyak 6.738 kasus. Data di Puskesmas Welahan jumlah kasus DM di Kecamatan Welahan adalah sebanyak 278 kasus. Dari 278 kasus Desa Welahan mempunyai kasus terbanyak yaitu 52 kasus. Berdasarkan penelitian oleh Firdausiya (2011), di kota Mojokerto hasil analisa statistik uji chi square yang dilakukan terhadap hubungan anatara penyakit diabetes melitus tipe I dengan usia awal menopause di RSUD DR. Wahidin Sudiro Husodo Mojokerto.

Mengukur parameter metabolik yang terkait dengan obesitas dan toleransi glukosa, fungsi kardiovaskular in vivo dengan pengukuran tekanan 
darah sistolik dan ex vivo dalam preparat jantung Langendorff yang terisolasi, cincin aorta toraks terisolasi bersama dengan histologi struktur dan fungsi hati oleh histologi dan biokimia plasma.Testoleransi glukosa dilakukan setelah menentukan konsentrasi glukosa darah puasa semalaman dalam menggunakan darah vena Medisense Precision Q.I.D.Kolagen adalah yang paling melimpah dan ada di mana-mana berasal dariprotein hewan, yang terdiri dari sekitar $30 \%$ dari total protein. Kolagen ada di semua jaringan ikat, termasuk kulit, tulang, tulang rawan, tendon dan pembuluh darah (Zhu, C ,2010,Kumar,2014)

Dilihat dari permasalahan diatas data wanita menopause yang mengalami Diabetes Mellitus semakin meningkat, dimana kita ketahui kadar gula darah dapat meningkat karena faktor gaya hidup, maka peneliti melakukan penelitian dengan judul "pengaruh pemberian suplemen kolagen terhadap kadar gula darah pada wanita menopause yang menderita diabetes mellitus di Wilayah kerja Puskesmas Curug Kabupaten Tangerang Tahun 2020"

\section{METODE}

Jenis penelitian ini penelitian kualitatif, desain penelitian yang digunakan adalah Quasi Experimen atau eksperimen semu dengan rancangan yang digunakan adalah One Group Pretest- Postest Designtanpa adanya kelompok kontrol tetapi sudah dilakukan observasi pertama (pretest) yang mungkin peneliti dapat menguji perubahan-perubahan yang terjadi setelah adanya eksperimen (postest), (Notoatmodjo,2010).

Populasi dalam penelitian ini adalah wanita menopause dengan diabetes mellitus di bulan janijuli di Wilayah Kerja Puskesmas Curug Kabupaten Tangerang. Teknik sampling mengunakan Total sampling dalam penelitian ini untuk mengetahui pengaruh pemberian suplemen kolagen terhadap kadar gula darah pada wanita menopause yang menderita Diabetes Mellitus dibutuhkan subyek sebanyak 20 wanita menopause, subjek dilakukan pengukuran gula darah sewaktu pada hari 1 sebelum diberikan suplemen kolagen selanjutnya subjek diberikan suplemen kolagen selama 1 bulan diminum $2 x$ sehari kemudian di lakukan pengukuran gula darah sewaktu di minggu ke 1 dan ke 4 bulan Juli 2020

Jenis data yang digunakan padapenelitian ini adalah data primer. Pengukuran kadar gula mengunakan glucometer yang dilakukan door to door

Instrumen yang digunakan adalahlembarobsevasiyang di gunakan dalam melakukan pengukuran kadar gula darah, nomor responden, nama responden, umur, nomor whatsapp

Analisa univariat digunakan untuk mendeskripsikan karakteristik responden dan kadar gula darah ditampilkan dalam table nilai rata kadar gula darah pretest dan post test analisis bivariate dilakukan untuk mengetahui pengaruh antara variable independent dan variabel dependen yaitu pengaruh konsumsi suplemen kolagen terhadap kadar gula darah wanita menopause dengan diabetes mellitus . berdasarkan jenis data/variable yang digunakan ( parametrik) maka uji statistic yang digunakan adalah Paired $T$ test.

\section{HASIL DAN PEMBAHASAN Analisis Univariat}

Dari Tabel 1 nilai rata-rata kadar gula darah sebelum dan sesudah Diberikan suplemen kolagen didapatkan hasil rata rata kadar gula darah ibu pretest 277,15 dengan standar deviasi 111,528 sedangkan untuk kadar gula darah minimum 103 dan kadar gula darah maximum 530. Dari table di atas, didapatkan hasil lainnya yaitu gula darah post test, dengan rata-rata 260,30 dengan standar deviasi 101,583 nilai minimum 118 dan nilai maximum 504.

Tabel 1.

Nilai Rata-rata Kadar Gula darah Sebelum dan Sesudah Diberikan suplemen kolagen Di Wilayah KerjaPuskesmas Curug Kabupaten Tangerang Tahun 2020

\begin{tabular}{ccccccc}
\hline Kadar Gula & N & $\%$ & Mean & SD & Min & Max \\
\hline Gula Darah Pre & 20 & 100 & 277,15 & 111,528 & 103 & 530 \\
GulaDarah Post & 20 & 100 & 260,30 & 101,583 & 118 & 504 \\
\hline
\end{tabular}

Table 2.

Pengaruh Pemberian Suplemen Kolagen Terhadap Kadar Gula Daarah pada wanita menopause yang menderita Diabetes Mellitus di Wilayah Kerja Puskesmas Curug KabupatenTangerang Tahun 2020 


\begin{tabular}{lcccc}
\hline \multicolumn{1}{c}{ Kadar Gula $(\mathbf{n = 2 0})$} & Mean & SD & T & $\boldsymbol{P}$ \\
\hline $\begin{array}{l}\text { Pre Test Minggu ke-1 } \\
\text { Post Test Minggu Ke-4 }\end{array}$ & 16.850 & 102.424 & 0,736 & 0,471 \\
\hline
\end{tabular}

Berdasarkan tabel 2 Pengaruh pemberian suplemen kolagen terhadap kadar gula daarah pada wanita menopause yang menderita diabetes mellitus maka didapatkan hasil dengan mean pretest minggu pertama 277.15 dan post test minggu ke empat didapatkan hasil rata-rata 260.30 sedangkan mean dari keduanya yaitu 16,850 dengan standar devisiasi 102,424 selain itu didapatkan juga nilai $P$ 0,471 > 0,05 maka didapatkan tidak adanya pengaruh antara sebelum perlakuan dan setelah perlakuan

\section{PEMBAHASAN}

Nilai Rata-rata kadar Gula darah Pada Wanita Menopause dengan Diabetes Mellitus Di Wilayah Kerja Puskesmas Curug Kabupaten Tangerang Tahun 2020

Hasil Penelitian yang dilakukan di Wilayah Kerja Puskesmas Curug Kabupaten Tangerang Tahun 2020 didapatkan hasil berdasarkan kadar gula darah sebelum dan sesudah diberikan suplemen kolagen didapatkan hasil rata rata kadar gula darah ibu pretest $277 \mathrm{gr} / \mathrm{dl}$ sedangkan untuk kadar gula darah minimum $103 \mathrm{gr} / \mathrm{dl}$ dan kadar gula darah maximum $530 \mathrm{gr} / \mathrm{dl}$. Selain itu didapatkan hasil lainnya yaitu gula darah post test dengan rata-rata $260 \mathrm{gr} / \mathrm{dl}$ dengan nilai minimum $118 \mathrm{gr} / \mathrm{dl}$ dan nilai maximum $504 \mathrm{gr} / \mathrm{dl}$.

Pemeriksaan kadar gula darah adalah jenis pemeriksaan yang digunakan untuk mengukur jumlah glukosa dalam darah. Pemeriksaan ini terutama dilakukan untuk memeriksa seseorang yang telah menderita diabetes dimana kadar gula darah seseorang mengalami peningkatan. PARKENI (Perkumpulan Endokrinologi Indonesia)

Pada tahun 2006 menjelaskan bahwa, kadar gula darah puasa yang berkisar $80-100 \mathrm{mg} / \mathrm{dl}$ dinyatakan normal. Seseorang dikatakan menderita diabetes mellitus (DM) jika memiliki kadar gula darah $>126 \mathrm{mg} / \mathrm{dl}$ (Lestari, 2013).

Hiperglikemia merupakan penyebab utama terjadinya kerusakan jaringan pada diabetes mellitus. Proses ini dimodifikasi dimodifikasi oleh perbedaan genetik individu dan faktor-faktor percepatan seperti hipertensi dan hiperlipidemia. Diabetes merusak sel secara selektif seperti sel endotel dan sel 32 mesangial yang mana kecepatan transport glukosa tidak menurun dengan cepat pada kondisi hiperglikemia sehingga glukosa dalam sel tinggi Hiperglikemia merupakan penyebab utama terjadinya kerusakan jaringan pada diabetes mellitus. Proses ini dimodifikasi dimodifikasi oleh perbedaan genetik individu dan faktor-faktor percepatan seperti hipertensi dan hiperlipidemia. Diabetes merusak sel secara selektif seperti sel endotel dan sel 32 mesangial yang mana kecepatan transport glukosa tidak menurun dengan cepat pada kondisi hiperglikemia sehingga glukosa dalam sel tinggi (Ban Camellia 2008 dalam hasanah 2014)

\section{Pengaruh Pemberian Suplemen Kolagen Terhadap Kadar Gula Darah Pada Wanita Menopause yang menderita Diabetes Mellitus Di Wilayah Kerja Puskesmas Curug Kabupaten Tangerang Bulan Tahun 2020}

Kolagen adalah protein utama yang menyusun komponen matriks ekstraseluler dan merupakan protein yang paling banyak ditemukan di dalam tubuh manusia. Kolagen tersususn atas tripel helix dari tiga rantai a polipeptida. Sekitar 30 bentuk rantai a terdapat pada 14 tipe kolagen. Kolagen tipe I, II dan III merupakan kolagen interstisial atau kolagen fibriler yang merupakan jumlah paling banyak. Tipe IV, V dan VI merupakan bentuk non fibriler dan terdapat di jaringan interstisial dan membrane basalis .16 Kolagen adalah protein utama yang menyusun komponen matriks ekstraseluler dan merupakan protein yang paling banyak ditemukan di dalam tubuh manusia. Kolagen tersususn atas tripel helix dari tiga rantai a polipeptida. Sekitar 30 bentuk rantai a terdapat pada 14 tipe kolagen. Kolagen tipe I, II dan III merupakan kolagen interstisial atau kolagen fibriler yang merupakan jumlah paling banyak. Tipe IV, V dan VI merupakan bentuk non fibriler dan terdapat di jaringan interstisial dan membrane basalis (Brownlee,2005)

Diabetes mellitus adalah kelompok penyakit metabolik yang ditandai dengan hiperglikemia yang diakibatkan oleh gangguan sekresi insulin, aksi insulin atau keduanya. Kondisi hiperglikemia kronik pada diabetes mellitus ini dihubungkan dengan terjadinya gangguan, disfungsi dan kegagalan berbagai organ terutama mata, ginjal, syaraf, jantung dan pembuluh darah (Cerielo,2008)

Beberapa penelitian telah menunjukkan bahwa pada DM terjadi peningkatan jumlah dan ekspresi kolagen. Beberapa faktor yang mempengaruhi ekspresi kolagen mesangial adalah glukosa darah, transforming growth factor, insulin dan angiotensin II (Erensoy, et all,2004) 
Glukosa darah yang tinggi berperan baik secara langsung maupun tidak langsung terhadap sintesa protein ECM, lamimin dan kolagen pada ginjal diabetik (Erensoy, et all,2004)

Kultur sel mesangial pada glukosa konsentrasi tinggi meningkatkan sintesa protein de nouvo terutama kolagen tipe Idan IV hal ini meniru efek dari rekombinan TGF-ß pada sintesa sel kolagen. Ekspresi gen sintesa kolagen dan protein pada hiperglikemia diaktifkan oleh TGF-ß endogen . Hal ini membuktikan bahwa TGF-ß adalah sitokin penting untuk menstimulasi sintesa kolagen pada hiperglikemia (Zizadeh f,et all,1994)

Metabolisme glukosa yang berlebihan akibat hiperglikemi, termasuk reaksi oksidasi memberikan akibat akumulasi ROS seperti hydrogen peroksid, anion superoksid and radical hydrogen . peran ROS pada DM akan menyebabkan 38 meningkatnya TGF$B$ dan sintesa kolagen. Berdasarkan hal tersebut sintesa kolagen dapat direduksi dengan menekan sintesa TGF- $\beta$ dengan menghambat akumulasi ROS menggunakan antioksidan. Produksi kolagen pada sel mesangial pada DM dapat dicegah dengan pemberian vitamin $\mathrm{E}$ atau taurine (W Catharine et,all,2002)

Suplemen antiaging terdiri dari Hidrolisat kolagen dihasilkan dari hidrolisis kolagen dengan bantuan enzim protease misalnya papain, bromelin dan kolagenase dalam kondisi yang terkontrol, memiliki bioaktivitas sebagai antioksidan, antimikroba, dan antihipertensi (Fan et al. 2013).

Karakteristik hirolisat kolagen adalah viskositas yang rendah, larut dalam air, tidak berwarna, alergenisitas rendah, memiliki kemampuan memperbaiki kulit yang baik sehingga merupakan bahan yang populer sebagai suplemen antiaging (litchenco et al. 2017).

Hidrolisat kolagen memiliki kemampuan dalam menghambat aktivitas tirosinase 15,44\% (Hong et al. 2019). Bahan yang dapat menghambat aktivitas tirosinase, kolagenase dan elastase merupakan salah satu bahan penyusun kosmetik untuk pemutih kulit, antipenuaan dan antikeriput. Penggunaan hidrolisat kolagen secara oral dapat meningkatkan echogenicity dermis dan elastisitas kulit dan mengurangi jumlah kerutan pada kulit (Campos et al. 2015)

Perubahan tingkat hormon tubuh pada wanita menopause dapat memicu fluktuasi kadar gula darah dan pada DM akan menghambat produksi kolagen didalam tubuh manusia (Ahmad,2019)

Manfaat kolagen antara lain: untuk penderita hipertensi, permasalahan urinari, yang berkaitan dengan osteoarthritis, rekayasa jaringan untuk implantasi pada manusia, dan penghambatan penyakit angiogenic, seperti komplikasi diabetes, obesitas, dan arthritis (Rehn et al., 2001).

Suplemen merupakan suatu bahan yang ditambahkan untuk memenuhi gizi di dalam tubuh, baik dalam bentuk cair, serbuk, maupun padat/tablet (ahmad,2019)

Pengunaan Kolagen juga dapat diaplikasikan dalam bentuk serbuk, tablet,pil dan dalam bidang pangan (edible casing), kosmetik (krim kulit,shampo, produk-produk perawatan rambut, cat kuku),dan medis (perbanyakan plasma, plasma pemekar, agen hemostatik, material benang bedah, perbaikan katup prostensis, perbaikan selaput mata,hemodialisis, tulang buatan, pebentukan oksigen membram, dan pemulihan operasi

Hasil penelitian ini dilakukan pemeriksaan gula darah sewaktu di minggu pertama (pretest) 277 $\mathrm{gr} / \mathrm{dl}$ dan post test minggu ke empat didapatkan hasil $260 \mathrm{gr} / \mathrm{dl}$ sedangkan mean dari keduanya yaitu 16,850 dengan standar devisiasi 102,424. Dapat di simpulkan bahwa pada wanita menopause Tidak terjadi peningkatan gula darah secara signifikan, dengan nilai $\mathrm{P}=0,471>0,05$ maka tidak ada perbedaan kadar gula darah pada wanita menopause dengan diabetes mellitus antara sebelum dan sesudah diberikan suplemen kolagen

Pemberian suplemen kolagen pada wanita menopause dengan diabetes mellitus penting dimana ibu membutuhkan kolagen untuk menjaga kesehatan jantung serta pembuluh darah sehingga wanita menopause dengan DM aman menkonsumsi suplemen kolagen dalam penelitian ini

\section{KESIMPULAN}

Berdasarkan hasil penelitian pengaruh pemberian suplemen kolagen terhadap kadar gula darah pada wanita menopause yg menderita diabetes mellitus di wilayah kerja Puskesmas Curug Kabupaten Tangerang tahun 2020dapat disimpulkan bahwa dari didapatkan mean sebelum diberikan perlakuan 277,15 gr/dl dan sesudah diberikaan perlakuan didapatkan hasil rata-rata $260,30 \mathrm{gr} / \mathrm{dl}$ mean dari keduanya yaitu 16,850 dengan standar devisiasi 102,424 . Nilai $P=0,471>0,05$ maka didapatkan tidak adanya pengaruh pemberian suplemen kolagen terhadap kadar gula darah pada wanita menopause dengan diabetes millitus .

\section{SARAN}

Diharapkan bagi peneliti selanjutnya dapat melalukan penelitian lebih lanjut tentang pemberian suplemen kolagen terhadap ekpresi kolagen dalam darah wanita menopause dengan jangka waktu yang lebih lama (3-6 bulan) dan mengembangkan 
variable-variabel lain yang belum diteliti dalam penelitian ini.

\section{DAFTAR PUSTAKA}

Alimul,Hidayat A.A., 2010. Metode Penelitian Kesehatan Paradigma Kuantitatif, Jakarta: Heath Books

Ahmad, M. G., Setyaningsih, I., \& Trilaksani, W. (2019). Formulasi dan bioaktivitas suplemen tablet berbasis Spirulina dan hidrolisat kolagen kulit ikan nila. Jurnal Pengolahan Hasil Perikanan Indonesia, 22(3), 453-463.

Alves, A. L., Marques, A. L., Martins, E., Silva, T. H., \& Reis, R. L. (2017). Cosmetic potential of marine fish skin collagen. Cosmetics, 4(4), 39

Belouafa, S., Bourja, L., Villain, S., Tayane, S., Bennamara, A., \& Abourriche, A. (2018). Biocomposite Based on Collagen/Calcium Salts Extraction from Sardine Scales. Smart Application and Data Analysis for Smart Cities (SADASC'18)

Bilek, S. E., \& Bayram, S. K. (2015). Fruit juice drink production containing hydrolyzed collagen. journal of functional foods, 14,562 569

Brownlee M, The Pathobiology of Diabetic Complications, Dabetes, 2005 June ; 54 : 1615-25

Budiman.2011.Penelitian Kesehatan Badung :Refika Aditama

Campos PMMBG, Melo MO, Calixto LS, Fossa MM. 2015. An oral supplementation based on hydrolyzed collagen and vitamins improves skin elasticity and dermis echogenicity: a clinical placebo controlled study. Clin Pharmacol Biopharm. 4(3):1-6.

Ceriello A, The Hyperglicemia-Induced "Metabolic Memory" : The new Challenge for the Prevention of CVD in Diabetes, Rev Esp Cardiol Supl. 2008;8:11-7C

Chandra, B. Metodolog iPenelitian Kesehatan.

Erensoy et al, Effects of ACE inhibition on expression of type IV collagen and laminin in renal glomeruli in experimental diabetes, Acta Histochem, 2004; 106 (4): 279-87

Fan J, Zhuang Y, Li B. 2013. Effect of collagen and collagen hydrolysate from jellyfish umbrella on histological and immunity changes of mice photoaging. Nutrients. (5):223-233

Felician, F. F., Xia, C., Qi, W., \& Xu, H. (2018). Collagen from marine biological sources and medical applications. Chemistry \& biodiversity, 15(5), e1700557.

Firdausiya, F. (2011). Hubungan Penyakit Diabetes Melitus Tipe 1 Dengan Usia Awal Menopause
Hong GP, Min SG, Jo YJ. 2019. Anti-oxidative and anti-aging activities of porcine byproduct collagen hydrolysates produced by commercial proteases:

Hasanah,Nunung (2014) Pemberian Ekstrak Etanol Daun Salam Untuk Menurunkan Ekspresi Fibronektin Mesangial Tikus Sprague Dawley DM. Masters thesis, Master Program of Biomedical Science

Hashim, P., Ridzwan, M. M., Bakar, J., \& Hashim, M. D. (2015). Collagen in food and beverage industries. International Food Research Journal, 22(1), 1

Hongdong, S., Bo, Li. (2017) Beneficial Effects of Collagen Hydrolysate: A Review on Recent Developments. Biomed J Sci \& Tech Res, 1(2): $1-4$

Katili, A. S. (2009). Struktur dan fungsi protein kolagen. Jurnal Pelangi IImu, 2(5).

Karyati, S. (2016). Usia menopause dan Kejadian Diabetes melitus. Jurnal IImu Keperawatan dan Kebidanan, 7(2).

Kumar, S., Sugihara, F., Suzuki, K., Inoue, N., Venkateswarathirukumara, S. (2014) A double blind Placebo controlled, randomized, clinical study on the effectiveness

Lestari, I. D. (2013). Pengaruh spesies rumput laut dan kadar gula terhadap kualitas nata sebagai materi booklet untuk masyarakat pesisir/Indah Lestari Dwi (Doctoral dissertation, Universitas Negeri Malang).

Litchenco S, Kempka AP, Prestes RC. 2017. Profiles of enzymatic hydrolysis of different collagens and derivating over time. Revista Brasileira de Tecnologia Agroindustrial. 11(1): 2165-2185

Nongonierma, AB., FitzGerald, RJ. (2014) Susceptibility of milk proteins derived peptides to Dipep

Notoatmodjo,S. 2012. Metodologi Penelitian Kesehatan. Jakarta: RinekaCipta

Nursalam. 2013. Metodologi Penelitian IImu Keperawatan: Pendekatan Praktis : Jakarta : Salemba Medika.

Nursalam. 2008. Konsepdan Penerapan MetodologiPenelitian IImu Keperawatan. Jakarta: Salemba Medika

Riccardi, G., Rivelles, AA. (1991) Effect of dietary fibre and carbohydrate on glucose and lipoprotein

Sari, W., Indrawati, L., \& Basuki Dwi Harjanto, M. M. (2012). Panduan lengkap kesehatan wanita. Penebar PLUS+.

Santoso, H., \& Ismail, H. (2009). Memahami krisis lanjut usia. BPK Gunung Mulia.

Sofian.2011.Sinopsis Obstetrijilid2.Jakarta : EGC 
Sugiyono. 2012. Metode Penelitian Kuantitatif Kualitatif dan R\&D. Bandung: Alfa beta

Stipcevic, T., Piljac, J., \& Berghe, D. V. (2006). Effect of different flavonoids on collagen synthesis in human fibroblasts. Plant foods for human nutrition, 61(1), 27-32.

Waluyo, S, \& Putra, M.B. (2010). The Book Of Antiaging Rahasia Awet Muda Mind-BodySpirit. Jakarta : PT Elex Media Komputindo

Whiteside Catharine snd Dlugosz, John A, mesangial Cell protein kinase $\mathrm{C}$ isozyme activation in the diabetic mileu, Am J Physiol Renal Physiol,
2002; 282: F975-80 effect of hydrolysis and ultrafiltration. Molecules. 24:1-14.

Zhu, C., Li, G., Peng, H., Zang, F., Chen, Y., Li, Y. (2010) Treatment with marine collagen peptides modulates glucose and lipid metabolism in Chinese patients with

Zizadeh Fuad N et al, Stimulation of Collagen Gene Expression and protein Synthesis in Murine mesangial Cells by High Glucose is Mediated by Autocrine Activation of Transforming Growth Factor- $\beta$, J. Clin. Invest, 1994 February; 93: 536-42 